\title{
SOURCES OF FINANCING TASKS FOR PUBLIC HIGHER EDUCATION INSTITUTIONS: FINDINGS IN LIGHT OF THEIR REPORTING
}

The purpose of this study is to recognize the share of self-generated sources of financing for activities of public higher education institutions as part of their general stream of financing. Therefore, the key question that will be answered in this study is: how is the structure of financing sources of a studied institution of higher education formed? In the theoretical section, findings were based on the results of literature research. In turn, in the empirical part, findings were based on the results of a case study supported by observation in a multi-field participating university. The entity's financial statements were also used. On the basis of the research results, the structure of financing sources for the studied public institution of higher education was determined, indicating the possibility of using the entity's financial reporting for this purpose. It was noticed, based on the classification of the sources of financial supply indicated in the literature, that they are heterogeneous - drawn from both the public and private sectors. An increase in the share of funds supplied from the private sector was also revealed. In turn, private sources mainly came from fees related to the teaching process. Private sources also included those from commercialization of research results. The research presented in the study has provided new knowledge about the structure of the financing sources of a public education of higher institution in the context of current conditions for its functioning. In particular, the research helps supplement the existing scarcity of knowledge about the share of self-generated financing for a public higher education institution in the general financing stream of its activities.

Keywords: sources of financing, university tasks, report, public higher education institutions.

Jel Codes: I23; M41; M49

\section{Introduction}

For over thirty years researchers have been providing arguments that higher education is an efficient engine of economic growth ${ }^{1}$ and social growth ${ }^{2}$. Despite this significant role, there is no consensus in the environment of practitioners and theorists as to how it should be financed so that it can effectively carry out the tasks assigned to it in this scope. A significant difficulty in developing a favorable option is the fact that in most European countries, higher education is largely free of charge ${ }^{3}$. In turn, in other socially

\footnotetext{
${ }^{1}$ Carnoy M., et al. (2013). University expansion in a changing global economy. Triumph of the BRICs? Stanford University Press, p. 5-8.

${ }^{2}$ Hyytinen H., Toom A. (2019). Developing a performance assessment task in the Finnish higher education context: Conceptual and empirical insights. British Journal of Educational Psychology. Vol. 89 No 3, p. 551563.

${ }^{3}$ Kwiek M. (2014). Przyszłość uniwersytetów w Europie: motywy dyskusji i ich polskie konteksty. Nauka i Szkolnictwo Wyższe. No. 1-2, p. 71-90.
} 
and economically developed countries, such as the United States, Great Britain, Australia and New Zealand, students have to pay considerable fees to higher education institutions. Also in these higher education systems, for some time, ways have been sought to significantly reduce the difficulties associated with potential students' access to this type of education ${ }^{4}$.

The last decade has also made a number of significant changes in financing of higher education in the European Union (EU). Until recently, the basic sources of funding for public higher education institutions in Europe were: negotiations between these institutions and the state regarding the amount awarded, calculation of the amount based on actual costs incurred by institutions and distribution of subsidies to individual budget items ${ }^{5}$ (Art. 80 section 1, Law on Higher Education and Science ${ }^{6}$ ). Currently, the main premise for changes being undertaken in this area is the pursuit of financial stability of higher education institutions while strengthening their social responsibility as perceived in the educational and scientific dimension ${ }^{7}$.

Hence, many European countries are looking for new, more effective social and economic methods of financing higher education institutions, which are often based on teaching and research activities. While the literature devotes a lot of attention to this issue when analyzing it from the perspective of financing the system of higher education institutions as a whole, researchers are much less likely to recognize this problem from the perspective of individual entities.

Focusing further research attention within Polish public higher education institutions, it can be stated that it is at the individual level (of individual entities higher education institutions) that specific problems are revealed, related to the low or insufficient - regarding tasks which have to be realized - efficiency of financing sources. These phenomena are usually accompanied by low (and in extreme cases very low) predictability of this efficiency in the long term and the tacit assumption about the homogeneity of the sources used at the level of all public higher education institutions ${ }^{8}$. Meanwhile, this assumption is met by the legislative possibilities for developing independent solutions in this area, which in fact leads to a significant individualization of financing sources ${ }^{9}$. As a result, financing sources of higher education institutions can be considered heterogeneous. However, undertaking exploration in this area requires insight into the structure of the use of such sources by particular entities. In this light, striving to fill in the existing inefficiency of knowledge, the purpose of this study is to recognize

\footnotetext{
${ }^{4}$ Long N.V. (2019). Financing higher education in an imperfect world. Economics of Education Review, Vol. 71, p. 23-31.

${ }^{5}$ Stachowiak-Kudła M., Kudła J. (2017). Financial regulations and the diversification of funding sources in higher education institutions: selected European experiences. Studies in Higher Education. Vol. 42 No. 9 ,

${ }^{6}$ Ustawa prawo o szkolnictwie wyższym i nauce z dnia 20 lipca 2018 r. Dz. U. 2018, poz. 1668 [Law on higher education and science of 20 July 2018, Journal of Laws 2018, item 1668].

${ }^{7}$ Communication from the Commission to the Council and the European Parliament - Delivering on the Modernisation Agenda for Universities - Education, Research and Innovation. (2006)

${ }^{8}$ The algorithm for the distribution of subsidies, and from 2019 - subventions contains certain parameters that, depending on the activity of "universities" (primarily research and teaching staff) in areas taken into account when shaping the amount of subvention received by universities, can work in a surprising, and certainly in a hard to predict, way.

${ }^{9}$ Section XII LoHEaS: Financing of the higher education and science system and the financial economy of a university
} 
the share of self-generated sources of financing the activity of a higher education institution in the general financing stream of its activities. Therefore, the key question that will be answered in this study is: how is the structure of financing sources for the studied higher education institution formed? The basis for implementing such a research project will include the analysis of a deliberately selected entity, i.e. a public higher education institution (university) with the status of a classical university. Such an approach - despite the lack of representativeness of the obtained research results - will reveal the complex structure of financing sources of public higher education institutions, and above all, it will allow to set and test an appropriate research procedure that can be used in further studies covering the entire population of public higher education institutions in Poland and other European countries.

At the same time, a supplementary question was posed in this study, the answer to which will indicate the share of various sources supplied by public funds in the general stream of financing for public higher education institutions.

The results obtained in the course of empirical research seem to be particularly significant not only from a cognitive, but also a utilitarian point of view. The findings may be important for managers of public higher education institutions in Poland in connection with the forthcoming reduction in the amount of subventions for public higher education institutions, resulting from the reduction (until 2023) of the "constant of transfer" (Table 1) and other changes contained in current legal regulations ${ }^{10}$.

The topic under review is part of the research area on the financing of public higher education institutions, which in light of existing literature ${ }^{11}$, is one of the current fields of scientific exploration on these entities, next to university management and system, quality of education and research, relationship between higher education and the labour market, access to education as well as internationalization and globalization of higher education.

In identifying sources of funding for public higher education institutions, existing knowledge on the subject related to public sector organizations was used, and with some adaptation, the knowledge related to private sector entities was able to be used as well. This approach in light of the findings of researchers ${ }^{12}$ is legitimate and allows better recognition of occurring economic phenomena, contributing to the building of new knowledge.

\footnotetext{
${ }^{10}$ Rozporządzenie Ministra Nauki i Szkolnictwa Wyższego z dnia 13 grudnia 2018 r. w sprawie sposobu podziału środków finansowych na utrzymanie i rozwój potencjału dydaktycznego oraz potencjału badawczego znajdujących się w dyspozycji ministra właściwego do spraw szkolnictwa wyższego i nauki oraz na zadania związane z utrzymaniem powietrznych statków szkolnych i specjalistycznych ośrodków szkoleniowych kadr powietrznych. Dz. U. 2018, poz. 2508 [Ordinance of the Minister of Science and Higher Education of 13 December 2018 on the distribution of financial resources for the maintenance and development of didactic potential and research potential at the disposal of the minister responsible for higher education and science, and for tasks related to the maintenance of aircraft school and specialist air personnel training centers. OJ 2018, item 2508].

${ }^{11}$ E.g. Kwiek M. (2014). Przysztość uniwersytetów w Europie: motywy dyskusji i ich polskie konteksty. Nauka i Szkolnictwo Wyższe. No. 1-2, p. 71-90.

${ }^{12}$ Hood C. (1991). A New Public Management for all seasons? Public Administration. Vol. 69 No 1, p. 3-19.
} 
Due to the undertaken problems, qualitative research methods were used, which, together with the research procedure, were presented in detail in the further part of this study as adequate to the phenomena studied in economics and finance ${ }^{13}$.

\section{Tasks and rules for financing public higher education institutions in Poland - Literature findings}

Much research on public higher education institutions focuses on the development of individual institutions or individual groups of institutions (e.g. Clark, 1998) ${ }^{14}$. Others stress the important role market forces play in promoting the importance of higher education (e.g. World Bank, 2000) ${ }^{15}$. Still others claim that global institutional environments are the most important cause of what is happening to higher education at local and national levels ${ }^{16}$. Much can be said about each of these concepts. Although, while everyone acknowledges that the nation-state plays a role in the process of change, everyone diminishes its powerful role in shaping the national higher education system in response to institutional inertia, the international institutional environment as well as global and national economic contexts.

Public higher education institutions have long been seen as organizations that have had a significant impact on economic development and the progress of civilization ${ }^{17}$. Therefore, according to scientists, they play an extraordinary role in society, transferring - owing to their long (often lasting for many centuries) duration - important values in time. From this perspective, the majority of short-term economic events were unnoticeable or even insignificant for them. Such a role of a university was strengthened by the traditional - Humboldt - perception of the tasks it faced, which boiled down to research and education. However, several decades ago, practitioners and theorists of this area noticed the need to broaden this concept. To meet these demands ${ }^{18}$ the term "enterprising university" was introduced, to describe those that became key to regional development. This term was then adopted by researchers ${ }^{19}$ to describe universities that successfully implement the so-called third mission ${ }^{20}$. The essence of third mission is to determine how a university (actually the people who create it) contributes to economic

13 Sagan A. (2016). Metodologia badań ekonomicznych. Wydawnictwo Uniwersytetu Ekonomicznego w Krakowie, Kraków.

14 Clark B.R. (1998). The entrepreneurial university: demand and response. Tertiary Education and Management. Vol. 4 No 1, p. 5-16.

${ }^{15}$ World Bank (2000). Higher education in developing countries: Peril and promise. Published for the Task Force on Higher Education and Society. Washington, D.C.: World Bank,

${ }^{16}$ Carnoy M., et al., op. cit, p. 5-8

${ }^{17}$ Vica Olariu G., Brad S., Fulea M. (2020). The sustainable university in the new economic context. FAIMA Business \& Management Journal. Vol. 8 No 1, p. 5-18; Leal Filho W., et al. (2019). The role of planning in implementing sustainable development in a higher education context. Journal of Cleaner Production. Vol. 235, p. 678-687.

${ }^{18}$ Etzkowitz H. (1983) Entrepreneurial scientists and entrepreneurial universities in American academic science. Minerva, Vol. 21, No 2-3, p. 198-233.

${ }^{19}$ Clark B.R. (1998). Op. cit.; Clark B.R. (2001). The entrepreneurial university: new foundations for collegiality, autonomy and achievement. Higher Education Management. Vol. 13 No 2, p. 9-24.

Woollard D., Zhang M., Jones O. (2007). Academic enterprise and regional economic growth: Towards an enterprising university. Industry and Higher Education, December, p. 387-391.

${ }^{20}$ Van Vught F. (1999). Innovative universities. Tertiary Education and Management. No. 5, p. 347-355. 
and social development through its research and education. In the discussion on an enterprising university, it is emphasized that by a more efficient and effective use of physical and intellectual property, universities can diversify their financial base, thereby gaining independence in this respect and a greater level of autonomy ${ }^{21}$.

As a result, this concept integrates obligatory (from the point of view of these entities) research and educational activity with an optional one, such as running a business, which is the result of scientific research or development work or as a support for basic tasks ${ }^{22}$. The implementation of these tasks at European, including Polish universities, is financed by funds flowing from at least three main streams, namely: directly from the state budget (by the government), from various government entities in research matters and from other public and private sector entities ${ }^{23}$. These findings were confirmed in $^{24}$ studies, according to which public universities are financed mainly from public funds, which come both from the budget of public authorities and are obtained by competing for project or targeted funds in dispositions of various public units. At the same time, these funds are supported by financial contributions of students (tuition fees) and private and social sector entities. The latter include revenues generated from relations with the private sector, philanthropic funds, such as obtaining funds for graduates, revenues generated by the provision of services and revenues obtained from financial or business activities. It can therefore be concluded that direct public funding is the most important source of income for universities in Europe and in most cases takes the form of general subsidies/subventions or targeted subsidies ${ }^{25}$.

However, also in the case of universities, it should be expected that achieving their higher financial stability will be associated with the use of more than one source of funding ${ }^{26}$. Hence, researchers are of the view that universities should diversify their sources of funding to expand and protect their financial stability, and thus make the effort to look for alternative sources of income. However, as literature demonstrates, diversifying funding sources alone is not sufficient to achieve financial stability, because other factors, such as trust between government and universities, are also important ${ }^{27}$.

On the other hand, the dominance of public funding does not preclude a high level of university stability, as demonstrated by the example of Great Britain (Scott 1995). At the same time, researchers ${ }^{28}$ stated that in most cases a higher share of financing

${ }^{21}$ Zhao F. (2004). Academic entrepreneurship: case study of Australian universities. The International Journal of Entrepreneurship and Innovation, Vol. 5 No 2, p. 91-97.

${ }_{22}$ Brennan M.C., McGowan P. (2006), Academic entrepreneurship: an exploratory case study. International Journal of Entrepreneurial Behavior \& Research, Vol. 12 No. 3, p. 144-164; Brennan M.C., Wall A.P., McGowan P. (2005), Academic entrepreneurship: Assessing preferences in nascent entrepreneurs, Journal of Small Business and Enterprise Development, Vol. 12 No. 3, p. 307-322.

${ }^{23}$ Clark B.R. (2004). Sustaining change in universities. Continuities in case studies and concepts. Maidenhead: Open University Press.

${ }^{24}$ Estermann, T., Bennetot Pruvot E. (2011). Financially sustainable universities II. European universities diversifying income streams. Brussels: European University Association.

${ }^{25}$ Stachowiak-Kudła M., Kudła J. (2017). Financial regulations and the diversification of funding sources in higher education institutions: selected European experiences. Studies in Higher Education. Vol. 42 No. 9, p. 1718-1735.

${ }^{26}$ Ibidem.

${ }^{27}$ Chiang, L. (2004). The relationship between university autonomy and funding in England and Taiwan. Higher Education, Vol. 48, p. 189-212.

${ }^{28}$ Leal Filho W., et al. (20190, op. cit. 
universities from private funds means a higher risk for universities because the private sector (as opposed to the public one) is not obliged to provide funds for higher education unless it brings clear benefits.

As a result, referring to the concept of Markowitz $(1952)^{29}$, which was then developed by Sharp $(1964)^{30}$ and Lintner $(1965)^{31}$ it can be stated that activities of public universities are financed from the following sources:

- public:

- guaranteed, which from the university's perspective are certain and depend on the assets owned (these can include tangible assets such as property ownership or other property rights, and even intangible assets such as reputation, academic standing or the number of students subsidized by the government),

- non-guaranteed, the acquisition of which requires action, often involves the need to compete with other entities for their acquisition,

- private:

- originating, among others, from students' tuition fees,

- $\quad$ originating from the sale of products and services for enterprises.

At the same time, the main feature that distinguishes these sources from each other is a different level of risk in the situation of their acquisition and use. While the first of them is characterized by a relatively low level of risk, the other two can be described by a definitely higher risk level, due to a high degree of uncertainty accompanying their acquisition (and sometimes and/or their settlement). Hence, it is noted that sometimes the managers of public universities are willing to give up additional funds for their activities, in this way reducing the level of risk undertaken to the value they tolerate. Researchers note that this is particularly visible among managers of entities accustomed to prosperous financing directly from budget funds who generally manifest aversion to managerial risk $^{32}$. However, one can observe links with development in these areas and the use of sources with a higher level of risk, including those from competitions for financing innovative teaching or research projects.

In this context, tuition fees are one of the alternative solutions to the stream of public funds. In Europe, the issue of tuition fees is solved in different ways. There are countries that do not charge tuition fees in public universities, but there are those where this amount is fixed, as well as those where the university can set fees, but their limit is set by the government. In addition, there are countries where universities freely set fees, but also countries where tuition fees are the result of negotiations between public authorities and higher education institutions ${ }^{33}$.

In addition, there is a link between spending the funds obtained on a competitive basis and high results of university activity in these areas.

\footnotetext{
${ }^{29}$ Markowitz H. (1952), Portfolio selection. The Journal of Finance, Vol 7 No 1, p. 77-91.

${ }^{30}$ Sharpe W. (1964). Capital asset prices: A theory of market equilibrium under conditions of risk. Journal of Finance, Vol. 19 No 3, p. 425-442.

${ }^{31}$ Lintner J. (1965). The valuation of risk assets and the selection of risky investments in stock portfolios and capital budgets. Review of Economics and Statistics, Vol. 47 No 1, p. 13-37.

${ }^{32}$ Stachowiak-Kudła M., Kudła J. (2017). Op. cit.

${ }^{33}$ Sokolovska A., Rainova L., Zatonatska T. (2019). Loan and grant support for students in the context of the diversification of funding sources for higher education. Ekonomika, Vol. 98 No 1, p. 111-123.
} 
However, in the opinion of researchers ${ }^{34}$, financing tasks of public universities should not be limited to funds transferred from the state budget. What's more, this issue becomes particularly important in the conditions of budget deficit, which forces diversification of funding sources while maintaining access to education services at this level of education and uninterrupted research ${ }^{35}$.

The need to diversify these sources towards stabilizing the financial situation of universities can be explained by indicating at least several reasons. Firstly, expenditure on public universities is one of the largest shares in consolidated budget expenditure in many countries, and due to the accumulation of problems in the area of public finances, governments are encouraged to save budget funds and cut funding for higher education. Secondly, social inequality persists despite an increase in public funding for higher education. Thirdly, the differences in education at private and public universities are blurring.

Efforts to ensure the efficient use of limited public resources of universities require diversification of funding sources by obtaining funds from all interested parties.

\section{Regulations on shaping the structure of sources of financing the activities of public higher education institutions in Poland}

Public universities in Poland do not have one source of funding for tasks that are extremely important for the society and the economy. The financing model for these public sector entities is complex, and the subvention allocated to universities from the budget of the Ministry of Science and Higher Education is currently the dominant source of financing for public universities.

Financing the activities of universities is determined by many factors that are governed by legal provisions established by the Ministry of Science and Higher Education and the Ministry of Finance ${ }^{36}$. Variables determining the amount of subsidy received by universities react to their changes depending on the weight assigned to them (Table 1).

From 2019, in accordance with the provisions of the Law on Higher Education and Science (LoHEaS), the statute sets out the rules for the organization and functioning of a university for the disposal of public university property (Article 34, par. 1, LoHEaS). The statute also regulates and defines the principles of managing financial and material resources owned by a university, as well as the principles of creating and changing the state of funds created at a university. The LoHEaS also established the rules for drawing up and approving a material and financial plan, as well as the method of accounting for costs arising at public universities. Therefore, universities are subject to the

\footnotetext{
${ }^{34}$ Ibidem.

${ }^{35}$ Ipate D.M., Pârvu I., Sandu C.F. (2017). Comparative study regarding higher education financing systems. Economics, Management, and Financial Markets, Vol. 12 No 2, p. 182-190.

${ }^{36}$ Ustawa o finansach publicznych z dnia 27 sierpnia 2009 r. Dz. U. Nr 157, poz. 1241 z późn. zm. [Act on public finances of August 27, 2009, Journal Of Laws No. 157, item 1241, as amended]; Ustawa Prawo o szkolnictwie wyższym i nauce z dnia 20 lipca 2018 r. Dz. U. 2018, poz. 1668 [Law on higher education and science of 20 July 2018, Journal of Laws 2018, item 1668].
} 
financing, planning and control regime ${ }^{37}$. Also the management control used in these units is to cause a quick response to adverse situations ${ }^{38}$.

A university is exempted from fees for perpetual usufruct of real estate of the Treasury, with the exception of fees specified in the provisions on the management of agricultural property of the Treasury ${ }^{39}$. Financing the system of higher education (Art. 7, par. 1, LoHEaS) is carried out on the principles set out in the LoHEaS (Section XII Financing of the system of higher education and science and financial management of a university).

Currently, the main source of financing the activities of public universities and implemented planned tasks is the subvention granted in accordance with the state budget plan and applicable law (Art. 365 of the LoHEaS). The change in the financing of the basic tasks of public universities, which took place in accordance with the LoHEaS, introduced the financing of the basic tasks of public universities with a subvention ${ }^{40}$, replacing the subsidy received by these units so far $^{41}$. The differences between the subvention and the subsidy are not precisely described in legal regulations (generally applicable and directly related to the functioning of public universities). The terms subvention and subsidy can be used interchangeably, although in Poland the subvention is associated with a general transfer and the subsidy is perceived as a targeted transfer.

\footnotetext{
${ }^{37}$ Thieme J.K. (2009). Szkolnictwo wyższe. Wyzwania XXI wieku. Polska-Europa-USA. Difin, Warszawa, p. 143; Pisarska A. (2013). Budżet jako plan działania oraz instrument zarzadzania szkoła wyższa (na przykładzie uczelni publicznej). Miscellanea Oeconomicae, Studia i materiały, $\mathrm{nr} 2$.

38 Sołtyk P. (2015). Naruszenia dyscypliny finansów publicznych $w$ jednostce samorzadu terytorialnego przedmiotem audytu wewnętrznego. Zeszyty Naukowe Uniwersytetu Szczecińskiego nr 864 Finanse, Rynki Finansowe, Ubezpieczenia nr 76, t. 2, p. 133; Pisarska A. (2014). Kontrola zarzadcza jako narzędzie ograniczajace ryzyko funkcjonowania szkót wyższych [Management control as a tool limiting the risk of functioning of universities]. Ekonomika i Organizacja Przedsiębiorstwa, Instytut Organizacji i Zarządzania w Przemyśle, No. 7, Warszawa, p. Str.: 19-30.; Pisarska A., Uwarunkowania i przydatność informacyjna audytu finansowego w szkołach wyższych [Conditions and informational usefulness of financial audit at universities]. [in:] Tworzenie Mazowieckiego Klastra Audytu i Consultingu Uwarunkowania rozwoju rynku rewizji finansowej w Polsce, Wasilewski M., Wydawnictwo SGGW, Warszawa, 2014 p. 83-94.

${ }^{39}$ Ustawa o gospodarowaniu nieruchomościami rolnymi Skarbu Państwa z dnia 19 października 1991 r., Dz. U. z 2019 r. poz. 817, 1080 [Act on the management of agricultural property of the Treasury of October 19, 1991, Journal of Laws 2019, item 817, 1080].

${ }^{40}$ There is no legal definition of a subvention. In the doctrine of the law of public finances, it has been accepted to define subventions as state-public benefits to other public entities of a non-returnable, general, unconditional and free nature. Pursuant to the provisions of the Act on public finances, expenditure of the state budget is allocated to general subventions for local government units (Art. 112 par. 1 item 3) and to subventions for political parties (Art. 112 par. 1 item 6). In accordance with the Act of November 13, 2003 on the income of local government units (i.e. Journal of Laws of 2010, No. 80, item 526, as amended) the general subvention for local government units consists of: compensatory part for municipalities, poviats and voivodships, educational part for communes, poviats and voivodships, balancing part for communes and poviats, regional part for voivodships.

Act of 27 August 2009 on public finances (Journal of Laws of 2013, item 855, as amended), Art. 112. http://sejm.gov.pl/Sejm7.nsf/BASLeksykon.xsp?id=63AE1CB1AFC5C5F1C1257A5600465DA7\&litera=S ${ }^{41}$ Subsidies are defined as funds from the state budget, the budget of local government units and state targeted funds that are subject to special settlement rules, based on the Act on public finances, separate acts or international agreements, to finance or co-finance public tasks. The Act on public finances also contains definitions of three types of subsidies: targeted (Art. 127), entity Art. 131) and subject (Art. 130). Act of 27 August 2009 on public finances (Journal of Laws of 2013, item 855, as amended), Art. 126, 127, $130,131$. http://sejm.gov.pl/Sejm7.nsf/BASLeksykon.xsp?t=s\&id=63AE1CB1AFC5C5F1C1257A5600465DA7\&q=dot acje;
} 
The Polish legislator used the terms: general subvention and targeted subsidies. See more on this topic ${ }^{42}$.

The subvention obtained by university managers can be distributed in accordance with internally established legal regulations. The possibility of having a subvention at a university results from the provisions of the LoHEaS and the university statute created autonomously.

The subvention is a free of charge and non-returnable financial assistance, most often granted by the state to particular entities in support of their activities. The subvention differs from the subsidy in that it is a legal claim, so its receipt is guaranteed by law. If it has been budgeted for a specific unit, it has to be transferred. However, unlike the subsidy, the way the funds from the subvention are used depends on the beneficiary itself, i.e. the awarding authority cannot impose what the money should be spent on.

The beneficiary does not have to compete with other entities or meet any additional requirements in order to receive a subvention. In relation to financing public universities, the situation is different (the algorithm for awarding funds applies).

A university may distribute the subvention funds on its own, allocating them for the implementation of its own and commissioned work (however, public universities must account for it in detail). The elements contained in this report include: four parts ${ }^{43}$ (A; B; C; D). The basic difference between a subsidy and a subvention is the discretionary nature of the former (which is why until 2018 the applicable algorithm for the distribution of subsidies was justified), while a subvention takes the form of a legal claim. At the same time, the legislator did not resign from determining its amount based on an algorithm, which makes this solution essentially hybrid.

The amount of the subsidy obtained until the end of 2018, and the subvention since 2019 is determined for individual public universities by taking into account the parameters presented in Table 1. The algorithm components included in the table affect the amount of funds obtained for the functioning and implementation of tasks by units. In all of the analyzed years, i.e. 2016-2019, the algorithm was built based on the number of students, doctoral students and academic teachers, in the years 2016 and 2019 it equaled 0.35, and in 2017 and 2018 it equaled 0.40 . The algorithm for allocating funds for public universities also includes an HR component.

The amount of the subsidy obtained until the end of 2018, and the subvention since 2019 is determined for individual public universities by taking into account the parameters presented in Table 1. The algorithm components included in the table affect the amount of funds obtained for the functioning and implementation of tasks by units. In all of the analyzed years, i.e. 2016-2019, the algorithm was built based on the number of students, doctoral students and academic teachers, in the years 2016 and 2019 it equaled 0.35, and in 2017 and 2018 it equaled 0.40. The algorithm for allocating funds for public universities also includes an HR component.

${ }^{42}$ Guziejewska B. (2003). Problemy klasyfikacji źródet finansowania samorzadu terytorialnego, Samorząd Terytorialny, Wyd. „KiK” Konieczny i Kruszewski, Warszawa, p. ; Guziejewska B. (2007). Subwencje i dotacje dla samorządu terytorialnego w polityce finansowej państwa, Gospodarka Narodowa Nr 4, p. 71-89.

${ }^{43}$ The areas covered in four parts of the report on the use of subventions are: A - the base subvention and its possible increases; B - part relating to fixed assets; C - information on depreciation; C - financing of investments related to the basic tasks of a university. 
Table 1. Subsidy/Subvention - a basic element of financing implemented university tasks - education activities and research activities and separate business activity (Self-generated external financing)

\begin{tabular}{|c|c|c|c|c|c|}
\hline \multicolumn{6}{|c|}{$\begin{array}{l}\text { Components of the subsidy/subvention allocation algorithm for universities affecting the subsidy/subvention } \\
\text { awarded }\end{array}$} \\
\hline \multicolumn{2}{|l|}{ In 2015 i $2016^{44}$} & \multicolumn{2}{|l|}{ In 2017 i $2018^{45}$} & \multicolumn{2}{|l|}{ In $2019^{46}$} \\
\hline $\begin{array}{l}\text { number of } \\
\text { students and } \\
\text { doctoral students, } \\
\text { number of } \\
\text { academic } \\
\text { teachers } \\
\end{array}$ & 0.35 & $\begin{array}{l}\text { number of students and } \\
\text { doctoral students, } \\
\text { number of academic } \\
\text { teachers }\end{array}$ & 0.40 & $\begin{array}{l}\text { number of students and } \\
\text { doctoral students, } \\
\text { number of academic } \\
\text { teachers }\end{array}$ & 0.35 \\
\hline HR component & 0.35 & - $\quad$ HR component & 0.45 & - HR component & 0.25 \\
\hline $\begin{array}{l}\text { - } \\
\text { proportional } \\
\text { development of } \\
\text { education } \\
\text { (students, full- } \\
\text { time doctoral } \\
\text { students) } \\
\end{array}$ & 0.10 & 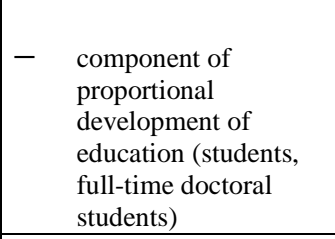 & - & 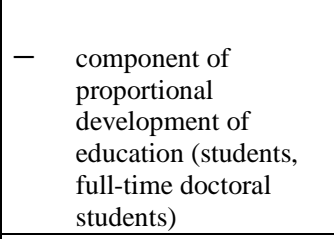 & - \\
\hline $\begin{array}{l}\text { - } \begin{array}{l}\text { research } \\
\text { component } \\
\text { (number of } \\
\text { grants) }\end{array} \\
\end{array}$ & 0.10 & 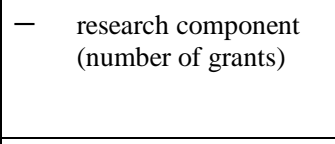 & 0.10 & $\begin{array}{ll}-\quad & \text { research component } \\
\text { (number of grants) }\end{array}$ & 0.25 \\
\hline $\begin{array}{l}\text { permission } \\
\text { component }\end{array}$ & 0.05 & - permission component & - & - permission component & \\
\hline $\begin{array}{ll}\text { - } & \text { student } \\
\text { exchange } \\
\text { component }\end{array}$ & 0.05 & $\begin{array}{l}\text { - internationalization } \\
\text { component }\end{array}$ & 0.05 & $\begin{array}{l}\text { - internationalization } \\
\text { component }\end{array}$ & 0.05 \\
\hline $\begin{array}{l}\text { project } \\
\text { component }\end{array}$ & - & - project component & - & - project component & 0.05 \\
\hline $\begin{array}{l}\text { R\&D } \\
\text { component }\end{array}$ & - & - $\quad$ R\&D component & - & - $\quad$ R\&D component & 0.05 \\
\hline
\end{tabular}

Source: author's own study on the basis of Law on Higher Education and Law on Higher Education and Science and ordinances of the Ministry of Science and Higher Education on the distribution of subsidy/subvention.

44 Rozporządzenie Ministra Nauki i Szkolnictwa Wyższego z dnia 27 marca 2015 r. w sprawie sposobu podziału dotacji z budżetu państwa dla uczelni publicznych i niepublicznych. Dz.U. 2015, poz. 463 [Ordinance of the Minister of Science and Higher Education of 27 March 2015 on the method of allocating subsidies from the state budget for public and private universities. OJ 2015, item 463].

${ }^{45}$ Rozporządzenie Ministra Nauki i Szkolnictwa Wyższego z dnia 7 grudnia 2016 zmieniające rozporządzenie w sprawie sposobu podziału dotacji z budżetu państwa dla uczelni publicznych i niepublicznych. Dz.U. 2016, poz. 2016 [Ordinance of the Minister of Science and Higher Education of 7 December 2016 amending the ordinance on the method of allocating subsidies from the state budget for public and private universities. OJ 2016, item 2016].

${ }^{46}$ Rozporządzenie Ministra Nauki i Szkolnictwa Wyższego z dnia 13 grudnia 2018 r. w sprawie sposobu podziału środków finansowych na utrzymanie i rozwój potencjału dydaktycznego oraz potencjału badawczego znajdujących się w dyspozycji ministra właściwego do spraw szkolnictwa wyższego i nauki oraz na zadania związane z utrzymaniem powietrznych statków szkolnych i specjalistycznych ośrodków szkoleniowych kadr powietrznych. Dz. U. 2018, poz. 2508 [Ordinance of the Minister of Science and Higher Education of 13 December 2018 on the distribution of financial resources for the maintenance and development of didactic potential and research potential at the disposal of the minister responsible for higher education and science, and for tasks related to the maintenance of aircraft school and specialist air personnel training centers. OJ 2018, item 2508]. 
Table 2 contains information regarding the guaranteed amount of subsidy/subvention received by public universities in 2015-2019. The entries presented in the table are based on legal regulations created by the Minister of Science and Higher Education.

The guaranteed amount of the subsidy granted to public universities (and from 2019 it is a subvention) is secured by the parameter - constant of transfer. This parameter equaled 0.65 in the years 2015 and 2016, in the years 2017-2019 it equaled 0.50, and in 2020 the constant of transfer was reduced to the amount of 0.45. In the following years it is planned to permanently decrease it by 0.05 per year, to the level of 0.30 in 2023. This parameter guarantees that every public university receives a subsidy/subvention at the level specified in legal regulations.

Table 2. Constant of transfer - giving financial security specified in legal regulations for the functioning of public universities

\begin{tabular}{|r|r|r|r|r|r|}
\hline \multicolumn{7}{|c|}{ Constant of transfer for subsidy/subvention for the years 2015-2023 } \\
\hline 2015 and 2016 & $2017-2019$ & 2020 & 2021 & 2022 & 2023 \\
\hline 0.65 & 0.50 & 0.45 & 0.40 & 0.35 & 0.30 \\
\hline
\end{tabular}

Source: author's own study on the basis of the ordinances of the Ministry of Science and Higher Education on the distribution of subsidy/subvention.

The constant of transfer indicates the level of financial security in relation to the amount of the subsidy from the previous financial year (Table 2).

Financing of public universities is complex, and funds, real estate and other things can be transferred to public universities from various units. Figure 1 shows the sources of funding for operational tasks carried out by public universities and ventures (usually implemented over a longer period of time). The main distribution of these sources is comprised of public (guaranteed and non-guaranteed) and private financing.

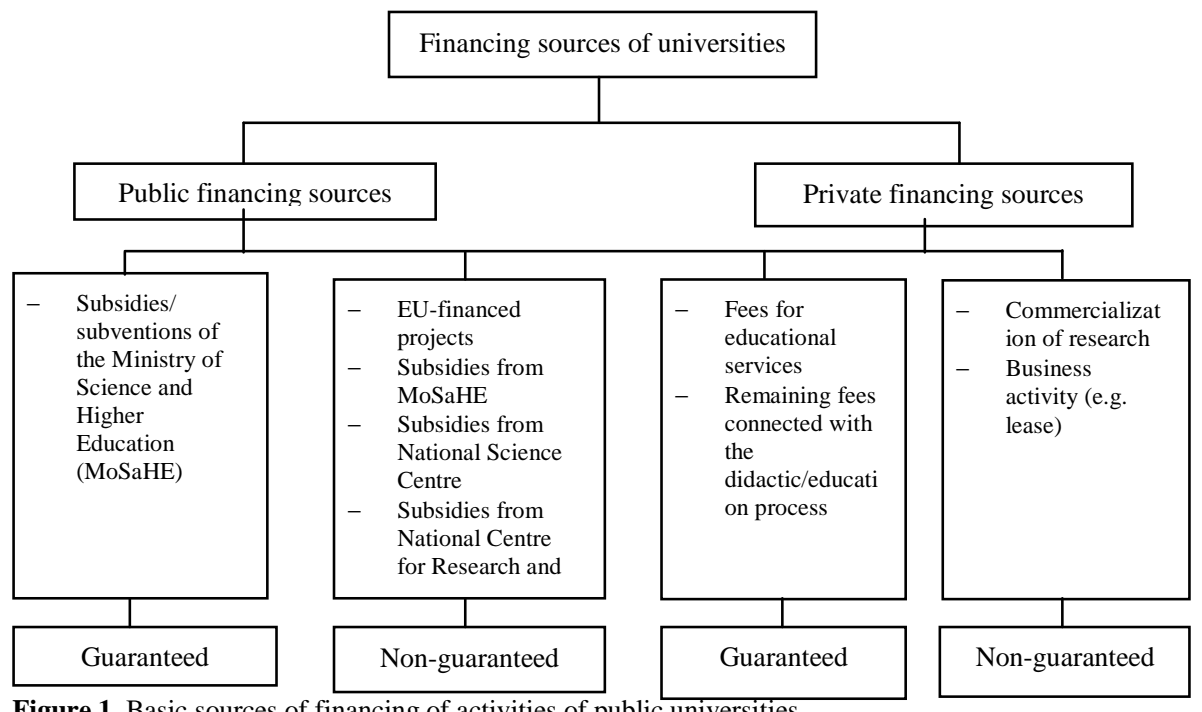

Figure 1. Basic sources of financing of activities of public universities

Source: author's own study. 
Financing of public universities is based primarily on revenues from the public sector (guaranteed and non-guaranteed sources). Financing from public funds is governed by the provisions of the law and it usually depends on the scientific potential of these entities. Private sources of financing are currently obtained mainly as fees for educational services and they come primarily from education at various levels (I, II and III degree), and they can also come from postgraduate studies, courses and trainings. Figure 1 presents the sources of financing occurring in all public higher education institutions that operate at the academic level. On the other hand, private sources of funding, which are not guaranteed by longer periods of cooperation, constitute above all the economic activity of public universities whose role is to support their statutory tasks. In recent years, activities involving the commercialization of research results and development works carried out at universities have become more and more important.

Usually, the largest by value stream of financing public universities are funds allocated to public universities as a basic subsidy, and from 2019 - the subvention allocated in order to maintain the teaching and research potential and other purposes, in accordance with the provisions of Art. 365, LoHEaS. Determining the amount of funds obtained by public universities (awarded as a subvention from the Ministry of Science and Higher Education) depends on the parameters specified in the allocation algorithm of subsidies (until the end of 2018), and from 2019 - subventions ${ }^{47}$. Since 2019, public universities can also obtain treasury bonds. In 2019 most public universities were allocated these financial market instruments; this was done through the Ministry of Science and Higher Education ${ }^{48}$.

Funds which are not guaranteed by public institutions, allocated based on the principles set out in separate legal regulations, include various types of targeted subsidies (subject and entity subsidies) ${ }^{49}$. They are granted to these organizationally and legally complex public entities from various sources (Art. 372 of the LoHEaS), including from local government units, a union of local government units or a metropolitan association ${ }^{50}$. The essence of financing which is not provided by public institutions lies in the fact that the source of obtaining funds is the external environment of an entity. It can also take place in a material and financial form ${ }^{51}$. The State Treasury and local government units may transfer e.g. real estate - on the terms and in the mode specified in the Act of 21 August 1997 on real estate management (Journal of Laws of 2018, item 2204, as amended 11) - to universities.

\footnotetext{
${ }^{47}$ Art. 365 LoHEaS - Financing the higher education system and public tasks of universities.

${ }^{48}$ Article 310, par. 1. Act on Provisions introducing the Law on Higher Education and Science of 3 July 2018. In 2019 and 2020, the minister competent for budget, at the request of the minister responsible for higher education and science, may transfer treasury securities to a public university to increase the core fund or to international scientific institute to increase the statutory fund. 2. The nominal value of liabilities under issued treasury securities transferred to public universities and international scientific institutes may not exceed PLN 3,000,000. PLN Act on Provisions introducing the Law on Higher Education and Science of 3 July 2018

${ }^{49}$ Rosen H.S. (1999). Public Finance. Fifth Edition, Irwin/Mc Graw-Hill.

${ }^{50}$ Article 1. par. 1. A metropolitan association is an association of local government units located in a given metropolitan area. 2. The metropolitan association includes: 1) municipalities located within the metropolitan area; 2) poviats in which at least one commune is located within the metropolitan area.

${ }^{51}$ Article 423 par. 1 . The State Treasury and local government units may transfer real estate to universities on the terms and in the manner specified in the Act of 21 August 1997 on real estate management (Journal of Laws of 2018, item 2204, as amended).
} 
University authorities can shape financing streams from public and private sources through more efficient management and more effective management of material resources, scientific and research potential, and making university assets available for use by third-parties for fees.

\section{Research methodology}

Obtaining the expected insight into the complexity of the studied phenomenon was associated with the use of an adequate research method. The initial analysis has shown the legitimacy of conducting research using qualitative methods, which are suggested to be used in situations where their subject includes phenomena that are difficult to be generalized $^{52}$ or those in which a significant cognitive deficit is noticeable ${ }^{53}$. In the case of the phenomenon in question (sources of financing for public universities), at least three reasons determined the choice of this method. First of all, each entity shapes its financial policy individually. As a result, it may differ from other entities when it comes to solutions adopted in the area of financing sources. A large individuality in shaping a university's financial policy results from the statute, in which each university is responsible for shaping the principles of management on its own. Secondly, there is a noticeable deficit of knowledge about this phenomenon in the area of public sector entities, and public universities with a high degree of organizational complexity in particular. Thirdly, the literature ${ }^{54}$ indicates quite generally the types of financial streams from which the operations of these entities are financed, while the specific sources (disposers of these funds) of their origin are not identified.

It was decided to fill in the identified knowledge gaps in the above-mentioned areas. The phenomenological and interpretative basis of qualitative research, in which the researcher has close contact with persons producing or presenting empirical data, has advantages and disadvantages ${ }^{55}$. The researcher is here oriented towards an exhaustive description of individual phenomena, together with an attempt to capture those external events that can qualitatively change the phenomena studied. Therefore, the research aims to identify the features of the studied phenomenon and reveal its uniqueness ${ }^{56}$. Therefore, empirical findings were made using the case study method supported by the participatory observation method. They are the result of research conducted by the author, one of the most commonly used qualitative research method in economic sciences $^{57}$ - an observation. This method enables orientation in significant phenomena occurring in the financial area of an organization. Its use is the basis for studying

\footnotetext{
${ }^{52}$ Chełpa S. (2003). Kwalifikacje kadr kierowniczych przedsiębiorstw przemystowych. Kierunki i dynamika zmian. Monografie i Opracowania No. 155, Prace Naukowe Akademii Ekonomicznej nr 996, p. 301-324.

53 Kostera M. (2003). Antropologia organizacji. Metodologia badań terenowych. Wydawnictwo Naukowe PWN. Warszawa,

${ }^{54}$ Stachowiak-Kudła M., Kudła J. (2017). op. cit.

${ }^{55}$ Stańczyk S., Triangulacja - taczenie metod badawczych i urzetelnienie badań. [in:] Podstawy metodologii badań w naukach o zarządzaniu, editor W. Czakon, Oficyna a Wolters Kluwer Business, Warszawa, 2011, p. 19-26.

${ }^{56}$ Chełpa S. (2003). Op. cit., p. 301-324

${ }^{57}$ Chybalski F., Matejun M. (2013). Organizacja jako przedmiot badań - od zbierania danych do analizy wyników. [in:] Adamik A. (editor), Nauka o organizacji. Ujęcie dynamiczne, Oficyna a Wolters Kluwer business, Warszawa, p. 93-151.
} 
documentation and other artifacts. At the same time, the study decided to use a hybrid method combining the features of the types of observations indicated in the literature ${ }^{58}$, namely:

- participatory - when the researcher is a participant in the organization/community he/she is researching, and thus is someone "from within". He/she interferes to some extent in the interactions among the members of the group he/she is watching and their behavior ${ }^{59}$. Therefore, the researcher enters a specific social environment, which allows him/her to better understand the structure of the studied group,

- non-participatory - if the researcher is not a participant in the organization/community he/she is researching. Non-participatory observation is made "from the outside", so as a passive observer, the researcher is not able to make a thorough interpretation without personally entering into the role of the objects of his/her analysis.

Such an approach is an expression of a departure from methodological fundamentalism, in which various research methods cannot be mixed, but it is also not eclecticism full of cognitive freedom, assuming the possibility of combining methods or fully unfettered anarchism deprived of scientific methods and maintained in the convention called "anything goes" 60 .

Its application, mainly with the intention of better capturing the occurring phenomena, was determined by numerous premises that scientists ${ }^{61}$ indicate in literature as necessary for its use, namely:

- better access to data,

- knowledge of the meaning of actions,

- knowledge of people,

- sense of the situation and the whole organization,

- opportunity to learn through experience.

The study is longitudinal in nature, as it has been conducted by the author continuously for 4 years. The timing of this study is not accidental. The 2016 introduction of a fundamental, as claimed in the literature ${ }^{62}$, change in the method of

${ }^{58}$ Stańczyk S. (2011). Op. cit., p. 19-26.

${ }^{59}$ Babbie E. (2004). Badania spoteczne w praktyce, PWN, Warszawa.

${ }^{60}$ Sułkowski $Ł$ (2005). Epistemologia $w$ naukach o zarządzaniu. PWE, Warszawa

${ }^{61}$ Kostera M. (2003). Op. cit.; Stańczyk S. (2011). Op. cit.; Yin R. (1994). Case study research: Design and methods, Sage Publications, Thousand Oaks, CA

${ }^{62}$ Rozporządzenie Ministra Nauki i Szkolnictwa Wyższego z dnia 27 marca 2015 r. w sprawie sposobu podziału dotacji z budżetu państwa dla uczelni publicznych i niepublicznych. Dz.U. 2015, poz. 463 [Ordinance of the Minister of Science and Higher Education of 27 March 2015 on the method of allocating subsidies from the state budget for public and private universities. OJ 2015, item 463]; Rozporzadzenie Ministra Nauki i Szkolnictwa Wyższego z dnia 7 grudnia 2016 zmieniające rozporządzenie w sprawie sposobu podziału dotacji z budżetu państwa dla uczelni publicznych i niepublicznych. Dz.U. 2016, poz. 2016 [Ordinance of the Minister of Science and Higher Education of 7 December 2016 amending the ordinance on the method of allocating subsidies from the state budget for public and private universities. OJ 2016, item 2016]; Rozporządzenie Ministra Nauki i Szkolnictwa Wyższego z dnia 13 grudnia 2018 r. w sprawie sposobu podziału środków finansowych na utrzymanie i rozwój potencjału dydaktycznego oraz potencjału badawczego znajdujących się w dyspozycji ministra właściwego do spraw szkolnictwa wyższego i nauki oraz na zadania związane $z$ utrzymaniem powietrznych statków szkolnych i specjalistycznych ośrodków szkoleniowych kadr powietrznych. Dz. U. 2018, poz. 2508 [Ordinance of the Minister of Science and Higher Education of 13 
calculating subsidies for public universities was considered as a threshold for their implementation.

In turn, the study covered a deliberately selected multi-field university. The criterion for its selection was the possibility of an in-depth insight into its financial and accounting areas and the fact that the types of sources of financing its tasks may slightly differ from other entities of this type and size class, as it was noticed on the basis of practical experience.

\section{Structure of sources of financing for a public university - findings based on a financial statement of this entity supported by the results of qualitative research}

Changes in the amount and structure of sources of financing the tasks of the audited university are presented in Figure 3. and Table 4. They contain data derived from additional information created as an element of the audited entity's financial statements and entries in their accounting books. Financial statements are prepared on the basis of Art. 45, par. 1 of the Accounting Act as at the date of closing the accounting books. When presenting the data of the audited entity, the author was guided by the identification of sources of their financing and division into those coming from the public finance system (as guaranteed by the Ministry of Science and Higher Education and those for which a university must compete) and those supplying the activities of a university from the private sector (guaranteed, e.g. fees for activities related to the didactic process and non-guaranteed - other private sources). The division with identification of financing sources is presented in Figure 3.

While studying the selected university, the author analyzed the financing of its goals from two main sources: from the public sector and from the private sector. Public universities realizing their goals focus on the implementation of these projects, the effects of which have the greatest impact on the parameters of the algorithm for the distribution of funds obtained from the resources of the Ministry of Science and Higher Education. Consequently, these activities are expected to increase their value. In the years 2016-2019 in the audited unit (multi-field university), the highest value of financial resources that were directly related to the basic tasks of the university were those guaranteed by the Ministry of Science and Higher Education, and their amount depended on the algorithms for their allocation. They were included in the ordinances of the Minister of Science and Higher Education.

In the analyzed period (Figure 3), in the years 2016-2019 there was a steady increase in the total value of funds from public sources, and in this scope it was a uniform trend from the amount of PLN 124986.3 in 2016 to PLN 162589.9 in 2019. The largest amount of public funding were funds from guaranteed sources, ranging from PLN 115596.1 in 2016 to the amount of PLN 135346.4 in 2019. However, nonguaranteed funds from public sources ranged from PLN 9030.2 in 2016 to

December 2018 on the distribution of financial resources for the maintenance and development of didactic potential and research potential at the disposal of the minister responsible for higher education and science, and for tasks related to the maintenance of aircraft school and specialist air personnel training centers. OJ 2018, item 2508]. 
PLN 27243.5 in 2019. However, the increase from non-guaranteed sources was not a growing trend.

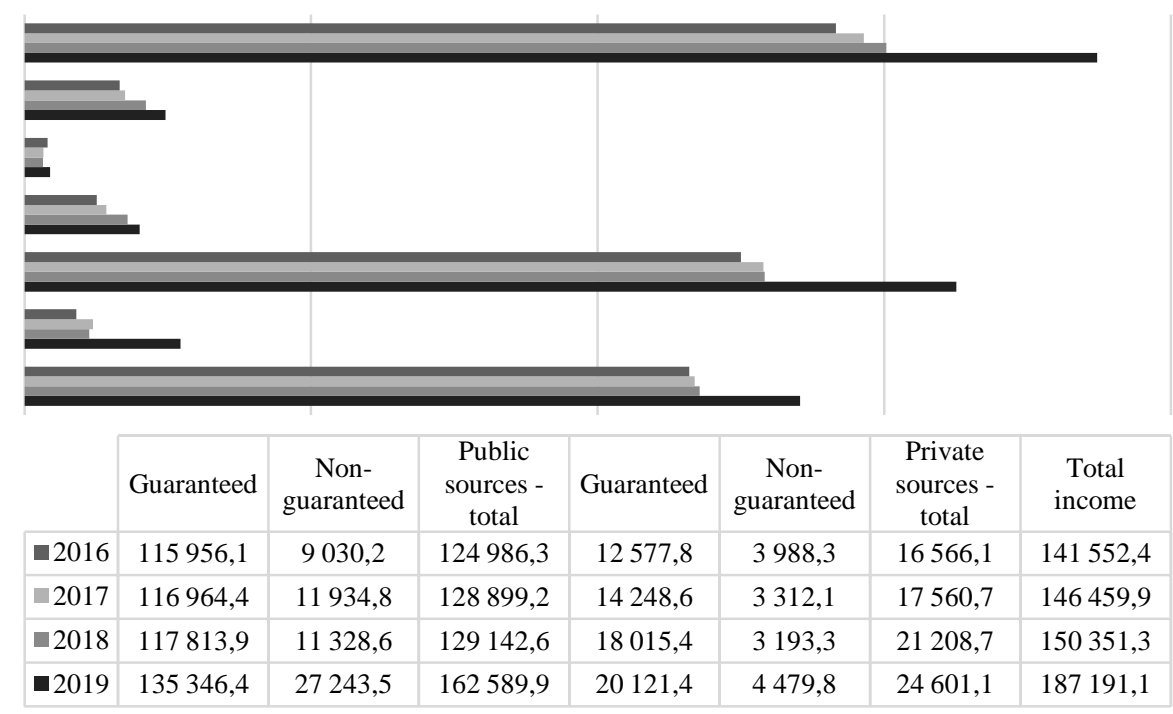

Figure 3. Financing tasks of public universities in the years 2016-2019 (in thousands PLN) Source: author's own study.

Private sources, which - at the researched university - mainly come from fees related to the didactic process, as well as from the commercialization of research results increased in each audited accounting year, in 2016 it was a total of PLN 16 566.1, and in 2019 it increased to PLN 24 601.1. The largest amount from private sources are those from guaranteed sources, the level of which increased from PLN 12577.8 in 2016 to PLN 20121.4 in 2019. The increase of this amount was a constant trend.

In the selected multi-field university (in the years 2016-2018), the share of guaranteed funds from the public sector in total public funding was found at over $90 \%$ except for 2019, when the guaranteed source of funding equaled $83.2 \%$ of total public funding (Table 4). On the other hand, public sources of financing constituted the largest percentage share in the total funding of the examined university in each of the examined years 2016-2019. In 2016 the share equaled $88.3 \%$, in $2017-88 \%$, in $2018-85.9 \%$, and in $2019-86.9 \%$ of all sources of financing examined (from the public and private sectors).

Analyzing private sources of financing it was found that their guaranteed part (mainly coming from fees for didactic processes) constitutes from $75.9 \%$ in 2016 to $84.9 \%$ in 2018 of total private financing in the analyzed period (2016-2019). Private non-guaranteed sources of financing ranged from $15.1 \%$ in 2018 to $24.1 \%$ in 2016 ; changes in this respect did not have a uniform trend. The share of private financing in the total sum of all sources of financing of the studied university increased in the period from 2016 to 2018 from $11.7 \%$ in 2016 to $14.1 \%$ in 2018; in this period it was 
a uniformly growing trend. On the other hand, in 2019 there was a decrease in private financing in the total value of financing of the analyzed university by 1 percentage point compared to 2018.

Table 4. Public and private financing sources of tasks of public higher education institutions from 2016 to 2019 (in thousands PLN)

\begin{tabular}{|c|c|c|c|c|c|c|c|}
\hline \multirow[b]{2}{*}{ Years } & \multicolumn{2}{|c|}{ Public sector } & \multirow{2}{*}{$\begin{array}{c}\text { Public } \\
\text { sources - } \\
\text { total }\end{array}$} & \multicolumn{2}{|c|}{ Private sector } & \multirow{2}{*}{$\begin{array}{c}\text { Private } \\
\text { sources - } \\
\text { total }\end{array}$} & \multirow[b]{2}{*}{ Total income } \\
\hline & Guaranteed & $\begin{array}{c}\text { Non- } \\
\text { guaranteed }\end{array}$ & & Guaranteed & $\begin{array}{c}\text { Non- } \\
\text { guaranteed }\end{array}$ & & \\
\hline \multirow[b]{3}{*}{2016} & 115956.1 & 9030.2 & 124986.3 & 12577.8 & 3988.3 & 16566.1 & 141552.4 \\
\hline & $92.8 \%$ & $7.2 \%$ & $100 \%$ & $75.9 \%$ & $24.1 \%$ & $100 \%$ & \\
\hline & & & $88.3 \%$ & & & $11.7 \%$ & $100 \%$ \\
\hline \multirow[b]{3}{*}{2017} & 116964.4 & 11934.8 & 128899.2 & 14248.6 & 3312.1 & 17560.7 & 146459.9 \\
\hline & $90.7 \%$ & $9.3 \%$ & $100 \%$ & $81.1 \%$ & $18.9 \%$ & $100 \%$ & \\
\hline & & & $88 \%$ & & & $12 \%$ & $100 \%$ \\
\hline \multirow[b]{3}{*}{2018} & 117813.9 & 11328.6 & 129142.6 & 18015.4 & 3193.3 & 21208.7 & 150351.3 \\
\hline & $91.2 \%$ & $8.8 \%$ & $100 \%$ & $84.9 \%$ & $15.1 \%$ & $100 \%$ & \\
\hline & & & $85.9 \%$ & & & $14.1 \%$ & $100 \%$ \\
\hline \multirow[b]{3}{*}{2019} & 135346.4 & 27243.5 & 162589.9 & 20121.4 & 4479.8 & 24601.1 & 187191.1 \\
\hline & $83.2 \%$ & $16.8 \%$ & $100 \%$ & $81.8 \%$ & $18.2 \%$ & $100 \%$ & \\
\hline & & & $86.9 \%$ & & & $13.1 \%$ & $100 \%$ \\
\hline
\end{tabular}

Source: author's own study..

\section{Summary}

As a result of radical changes in the principles of functioning of public universities that have taken place over the last two years, the attention of managers of these entities has been focused mainly on the implementation of tasks resulting from the scientific evaluation of units, having an impact on the algorithm for the distribution of subsidies. To a lesser extent, this attention is directed to ensuring medium or long-term financial stability of these entities. Perhaps the reason for this is the sense of stability in this respect that is provided by public funding. However, in light of the applicable law, such an approach can be hazardous and the sense of stability of financing from this source may be illusory. Hence, the recognition of the structure of financing sources, which was done in this study, seems to be of primary importance in terms of making possible changes in this respect.

On the basis of the conducted study, the structure of financing sources of the studied public university was determined, indicating the possibility of using the entity's financial reporting for this purpose.

Research on university funding sources was conducted in a public multi-field university, whose activities are financed for the most part from the budget of the Ministry of Science and Higher Education.

It was noticed, based on the classification of sources of financial supply indicated in the literature, that they are heterogeneous. In part they are located in the public sector and in other part - in the private sector.

Analyzing public sources of financing the activities of a selected public university, their greatest value was found in the area of guaranteed public financing. At the same time, while examining (guaranteed and non-guaranteed) public funding sources for 2016-2019, there was a steady increase in their total value; in this respect it was a uniform trend. Analyzing public funds for the implementation of the studied university's tasks, it can be stated that in the years 2016-2018 the share of guaranteed financial resources from the public sector was at the level of over $90 \%$, except for 2019, when this source of financing constituted $83.2 \%$ of total public funding. 
On the other hand, public sources of financing constituted the largest percentage share in total financing (by analyzing public and private sources jointly) of the studied university in each of the examined years 2016-2019. However, it was a downward trend, except for 2019, when there was a slight increase in this respect to the level of $86.9 \%$.

Despite all of the above, the largest share of public funds (from guaranteed and nonguaranteed sources jointly) in the total funding of the university (from public and private funds) in the analyzed period was found in 2016 , at the level of $88.3 \%$. This indicates an increase in the share of funding for this university from private sector funds. Private sources mainly come from fees related to the teaching process. Private sources are also those from commercialization of research results. Both groups of funds from the private sector increased in each audited financial year; in 2016 it was a total of PLN 16,566.1, and in 2019 it increased to PLN 24,601.1. While analyzing these sources of financing it was found that their guaranteed part constitutes from $75.9 \%$ in 2016 to $84.9 \%$ in 2018 of total private financing in the analyzed period (2016-2019). However, private non-guaranteed sources of financing ranged from $15.1 \%$ in 2018 to $24.1 \%$ in 2016; changes in this respect did not have a uniform trend. The share of private financing in the total sum of all sources of financing of the studied university increased in the period from 2016 to 2018 from $11.7 \%$ to $14.1 \%$, respectively; in this period it was a uniformly growing trend. A slight decrease in this share in general university financing occurred in 2019 to the level of $13.1 \%$.

Increasing the share of financial resources from the commercialization of research results in the total volume of task financing demonstrates the growing importance of the entrepreneurial university idea, which recently seems to be one of the university's major activities.

The analysis of legal regulations in the scope of financing the operations of public universities clearly indicates that the amount of subvention guaranteed by the state will decrease in the coming years. This, in turn, from the point of view of managers of these entities should lead them to intensify not only scientific activity, but also simultaneously stimulate entrepreneurial activity, which must soon become an effective source of financial support for this type of university.

Therefore, it is worth conducting further (on a broad sample of universities) research aimed at developing a model of the structure of financing sources for public universities. It can be assumed that this would be extremely helpful in the activities of managers of these entities in the coming years.

In this context, in the course of further research, it seems reasonable to recognize the financial results of these entities informing about the effectiveness of the use of funds they obtain from various sources.

\section{References}

Babbie E. (2004). Badania spoteczne w praktyce, PWN, Warszawa.

Brennan M.C., McGowan P., Academic entrepreneurship: an exploratory case study. International Journal of Entrepreneurial Behavior and Research. No. 12(3), 2006

Brennan M.C., Wall A.P., McGowan P., Academic entrepreneurship. Assessing preferences in nascent entrepreneurs. Journal of Small Business and Enterprise Development. No. 12(3), 2005

Carnoy M., et al. (2013). University expansion in a changing global economy. Triumph of the BRICs? Stanford University Press, p. 5-8.

Chełpa S. (2003). Kwalifikacje kadr kierowniczych przedsiębiorstw przemystowych. Kierunki $i$ dynamika zmian. Monografie i Opracowania No. 155, Prace Naukowe Akademii Ekonomicznej nr 996, p. 301-324.

Chiang, L., The Relationship Between University Autonomy and Funding in England and Taiwan. Higher Education 48, 2004 
Chybalski F., Matejun M. (2013). Organizacja jako przedmiot badań - od zbierania danych do analizy wyników. [in:] Adamik A. (editor), Nauka o organizacji. Ujęcie dynamiczne, Oficyna a Wolters Kluwer business, Warszawa, p. 93-151.

Clark B.R. (1998). The entrepreneurial university: demand and response. Tertiary Education and Management. Vol. 4 No 1, p. 5-16.

Clark B.R., The entrepreneurial university: new foundations for collegiality, autonomy and achievement. Higher Education Management. No. 13(2), 2001

Clark, B. R. (2004). Sustaining Change in Universities. Continuities in Case Studies and Concepts. Maidenhead: Open University Press.

Communication from the Commission to the Council and the European Parliament - Delivering on the Modernisation Agenda for Universities - Education, Research and Innovation, 2006

Estermann, T., Bennetot Pruvot E. (2011). Financially sustainable universities II. European universities diversifying income streams. Brussels: European University Association.

Etzkowitz H. (1983) Entrepreneurial scientists and entrepreneurial universities in American academic science. Minerva, Vol. 21, No 2-3, p. 198-233.

Guziejewska B. (2003). Problemy klasyfikacji źródet finansowania samorządu terytorialnego, Samorząd Terytorialny, Wyd. „KiK” Konieczny i Kruszewski, Warszawa.

Guziejewska B. (2007). Subwencje $i$ dotacje dla samorzadu terytorialnego $w$ polityce finansowej państwa, Gospodarka Narodowa Nr 4, p. 71-89.

Hood C. (1991). A New Public Management for all seasons? Public Administration. Vol. 69 No 1, p. 3-19.

Hyytinen H., Toom A. (2019). Developing a performance assessment task in the Finnish higher education context: Conceptual and empirical insights. British Journal of Educational Psychology. Vol. 89 No 3, p. 551-563.

Ipate, D.M., Pârvu, I., Sandu, C.F., Comparative study regarding higher education financing systems. Economics, Management, and Financial Markets 12(2), 2017

Kostera M. (2003). Antropologia organizacji. Metodologia badań terenowych. Wydawnictwo Naukowe PWN. Warszawa,

Kwiek M. (2014). Przyszłość uniwersytetów w Europie: motywy dyskusji i ich polskie konteksty. Nauka i Szkolnictwo Wyższe. No. 1-2, p. 71-90.

Lintner, J., The Valuation of Risk Assets and the Selection of Risky Investments in Stock Portfolios and Capital Budgets. Review of Economics and Statistics 47 (1): 1965

Long N.V. (2019). Financing higher education in an imperfect world. Economics of Education Review, Vol. 71, p. 23-31.

Markowitz H. (1952), Portfolio selection. The Journal of Finance, Vol 7 No 1, p. 77-91.

Pisarska A. (2013). Budżet jako plan działania oraz instrument zarzadzania szkoła wyższa (na przyktadzie uczelni publicznej) [The budget as an action plan and university management instrument (on the example of a public university)]. [in:] Miscellanea Oeconomicae, Studia i materiały, year 17, No. 2/2013, Wydawnictwo Uniwersytetu Jana Kochanowskiego w Kielcach, Kielce.

Pisarska A. (2014). Kontrola zarządcza jako narzędzie ograniczajace ryzyko funkcjonowania szkót wyzszych [Management control as a tool limiting the risk of functioning of universities]. Ekonomika i Organizacja Przedsiębiorstwa, Instytut Organizacji i Zarządzania w Przemyśle, No. 7, Warszawa.

Pisarska A. (2014). Uwarunkowania i przydatność informacyjna audytu finansowego $w$ szkołach wyższych [Conditions and informational usefulness of financial audit at universities]. [in:] Tworzenie Mazowieckiego Klastra Audytu i Consultingu Uwarunkowania rozwoju rynku rewizji finansowej w Polsce, Wasilewski M., Wydawnictwo SGGW, Warszawa, 2014 Str.: 83-94.

Rosen H.S. (1999). Public Finance. Fifth Edition, Irwin/Mc Graw-Hill.

Rozporządzenie Ministra Nauki i Szkolnictwa Wyższego z dnia 25 kwietnia 2012 r. w sprawie określenia wzoru rocznego sprawozdania z działalności uczelni albo związku uczelni oraz wzoru 
sprawozdania z wykonania planu rzeczowo-finansowego [Regulation of the Minister of Science and Higher Education of 25 April 2012 on determining the template for the annual report on the activities of the university or university association and the template for the report on the implementation of the material and financial plan].

Rozporządzenie Ministra Nauki i Szkolnictwa Wyższego z dnia 27 marca 2015 r. w sprawie sposobu podziału dotacji z budżetu państwa dla uczelni publicznych i niepublicznych. Dz.U. 2015, poz. 463 [Ordinance of the Minister of Science and Higher Education of 27 March 2015 on the method of allocating subsidies from the state budget for public and private universities. OJ 2015, item 463].

Rozporządzenie Ministra Nauki i Szkolnictwa Wyższego z dnia 7 grudnia 2016 zmieniające rozporządzenie w sprawie sposobu podziału dotacji $\mathrm{z}$ budżetu państwa dla uczelni publicznych i niepublicznych. Dz.U. 2016, poz. 2016 [Ordinance of the Minister of Science and Higher Education of 7 December 2016 amending the ordinance on the method of allocating subsidies from the state budget for public and private universities. OJ 2016, item 2016].

Rozporządzenie Ministra Nauki i Szkolnictwa Wyższego z dnia 13 grudnia 2018 r. w sprawie sposobu podziału środków finansowych na utrzymanie i rozwój potencjału dydaktycznego oraz potencjału badawczego znajdujących się w dyspozycji ministra właściwego do spraw szkolnictwa wyższego i nauki oraz na zadania związane z utrzymaniem powietrznych statków szkolnych i specjalistycznych ośrodków szkoleniowych kadr powietrznych. Dz. U. 2018, poz. 2508 [Ordinance of the Minister of Science and Higher Education of 13 December 2018 on the distribution of financial resources for the maintenance and development of didactic potential and research potential at the disposal of the minister responsible for higher education and science, and for tasks related to the maintenance of aircraft school and specialist air personnel training centers. OJ 2018, item 2508].

Sagan A. 2016). Metodologia badań ekonomicznych [Methodology of economic research]. Wydawnictwo Uniwersytetu Ekonomicznego w Krakowie, Kraków.

Scott, P. (1995). The Meaning of Mass Higher Education. Buckingham: Open University Press.

Sołtyk P. (2015). Naruszenia dyscypliny finansów publicznych $w$ jednostce samorządu terytorialnego przedmiotem audytu wewnętrznego. Zeszyty Naukowe Uniwersytetu Szczecińskiego nr 864 Finanse, Rynki Finansowe, Ubezpieczenia nr 76, t. 2, p. 133;

Sharpe W. (1964). Capital asset prices: A theory of market equilibrium under conditions of risk. Journal of Finance, Vol. 19 No 3, p. 425-442.

Sokolovska A., Rainova L., Zatonatska T. (2019). Loan and grant support for students in the context of the diversification of funding sources for higher education. Ekonomika, Vol. 98 No 1, p. 111-123.

Stachowiak-Kudła M., Kudła J. (2017). Financial regulations and the diversification of funding sources in higher education institutions: selected European experiences. Studies in Higher Education. Vol. 42 No. 9.

Stańczyk S. (2011). Triangulacja - tączenie metod badawczych i urzetelnienie badań [Triangulation - combining research methods and research reliability]. [in:] Podstawy metodologii badań w naukach o zarządzaniu, editor W. Czakon, Oficyna a Wolters Kluwer Business, Warszawa, 2011

Sułkowski Ł (2005). Epistemologia w naukach o zarzadzaniu. PWE, Warszawa.

Thieme J.K. (2009). Szkolnictwo wyższe. Wyzwania XXI wieku. Polska-Europa-USA [Higher education. Challenges of the 21 st century. Polish-US-Europe]. Difin, Warszawa.

Ustawa o finansach publicznych z dnia 27 sierpnia 2009 r. Dz. U. Nr 157, poz. 1241 z późn. zm. [Act on public finances of August 27, 2009, Journal Of Laws No. 157, item 1241, as amended] Ustawa o gospodarowaniu nieruchomościami rolnymi Skarbu Państwa z dnia 19 października 1991 r., Dz. U. z 2019 r. poz. 817, 1080 [Act on the management of agricultural property of the Treasury of October 19, 1991, Journal of Laws 2019, item 817, 1080]. 
Ustawa o rachunkowości z dnia 29 września 1994 r. Dz. U. Nr 121, poz. 591 z późn. zm. [Accounting Act of September 29, 1994, Journal of Laws No. 121, item 591 as amended]

Ustawa prawo o szkolnictwie wyższym i nauce z dnia 20 lipca 2018 r. Dz. U. 2018, poz. 1668

[Law on higher education and science of 20 July 2018, Journal of Laws 2018, item 1668]

Ustawa Przepisy wprowadzające ustawę - Prawo o szkolnictwie wyższym i nauce z dnia 3 lipca 2018 r. Dz.U. 2018 r. poz. 1669 [Act on provisions introducing the Law on Higher Education and Science of 3 July 2018, Journal of Laws 2018, item 1669]

Ustawa o związkach metropolitalnych z dnia 9 października 2015 r. Dz.U. Nr 2015, poz. 1890 [Act on metropolitan unions of October 9, 2015, Journal of Laws No. 2015, item 1890]

Van Vught F. (1999). Innovative universities. Tertiary Education and Management. No. 5, p. 347-355 .

Vica Olariu G., Brad S., Fulea M. (2020). The sustainable university in the new economic context. FAIMA Business \& Management Journal. Vol. 8 No 1, p. 5-18;

Leal Filho W., Skanavis C., Kounani A., Brandli L., Shiel Ch, Paço A., Pace P., Mifsud M., Beynaghi A., Price E., Salvia A.L, Will M., Shula K. (2019). The role of planning in implementing sustainable development in a higher education context. Journal of Cleaner Production. Vol. 235, p. 678-687.

Woollard D., Zhang M., Jones O. (2007). Academic enterprise and regional economic growth: Towards an enterprising university. Industry and Higher Education, December, p. 387-391.

World Bank (2000). Higher education in developing countries: Peril and promise. Published for the Task Force on Higher Education and Society. Washington, D.C.: World Bank,

Zhao F. (2004). Academic entrepreneurship: case study of Australian universities. The International Journal of Entrepreneurship and Innovation, Vol. 5 No 2, p. 91-97.

\section{Źródła finansowania zadań publicznych szkół wyższych: ustalenia w świetle ich sprawozdawczości}

\section{Streszczenie}

Celem opracowania jest rozpoznanie udziału źródeł własnych finansowania działalności publicznej uczelni wyższej w ogólnym strumieniu finansowania jej działalności. W związku z tym kluczowe pytanie, na jakie zostanie udzielona odpowiedź w tym opracowaniu dotyczy tego, jak ukształtowana jest struktura źródeł finansowania badanej uczelni? W części teoretycznej ustalenia oparto na wynikach badań literatury. Z kolei w części empirycznej ustalenia te oparto na wynikach studium przypadku wspartych obserwacją uczestniczącą w uniwersytecie wielodziedzinowym. Wykorzystano także sprawozdania finansowe tego podmiotu. Na podstawie wyników przeglądu literatury oraz badań empirycznych ustalono ukształtowanie struktury źródeł finansowania poddanej badaniu uczelni publicznej, wskazując na możliwość wykorzystania w tym celu sprawozdawczości finansowej podmiotu. Zauważono, kierując się klasyfikacją źródeł zasilania finansowego wskazywana w literaturze, że sa one heterogeniczne. W części są one ulokowane w sektorze publicznym, a w części w sektorze prywatnym. Odsłonięto także wzrost udziału zasilania badanej uczelni środkami z sektora prywatnego. Z kolei źródła prywatne pochodzą głównie $\mathrm{z}$ opłat związanych $\mathrm{z}$ procesem dydaktycznym. Źródłami prywatnymi są także te z komercjalizacji wyników badań naukowych. Przedstawione w opracowaniu badania dostarczyły nowej wiedzy o strukturze źródeł finansowania uczelni publicznej w kontekście aktualnych uwarunkować jej funkcjonowania. W szczególności przyczyniły się do uzupełnienia istniejącego niedostatku wiedzy o udziale źródeł własnych finansowania działalności publicznej uczelni wyższej w ogólnym strumieniu finansowania jej działalności. 
Słowa kluczowe: źródła finansowania, zadania uczelni, sprawozdania finansowe, uczelnie publiczne

JEL Codes: I23; M41; M49

Information about author:

Dr Aleksandra Pisarska

Uniwersytet Jana Kochanowskiego w Kielcach

Wydział Prawa i Nauk Społecznych

Katedra Ekonomii i Finansów

ul. Uniwersytecka 15, 25-406 Kielce

e-mail: apisarska@ujk.edu.pl

ORCID: 0000-0002-8165-0691 